\title{
Application of Zinc Mitigates the Salt-Induced Effects on Growth of Soybean (Glycine max L.)
}

\author{
Sadia Afrin, Nahid Akhtar*, Feroza Hossain \\ Plant Physiology and Biochemistry Laboratory, Department of Botany, Jahangirnagar University, Dhaka, Bangladesh \\ Email address: \\ nahid_akhtar98@yahoo.com (N. Akhtar) \\ ${ }^{*}$ Corresponding author \\ To cite this article: \\ Sadia Afrin, Nahid Akhtar, Feroza Hossain. Application of Zinc Mitigates the Salt-Induced Effects on Growth of Soybean (Glycine max L.). \\ International Journal of Ecotoxicology and Ecobiology. Vol. 6, No. 3, 2021, pp. 59-64. doi: 10.11648/j.ijee.20210603.13
}

Received: June 19, 2021; Accepted: July 14, 2021; Published: July 29, 2021

\begin{abstract}
Salinity is a major issue restricting sustainable soybean production in arid and semi-arid regions of the world. Zinc is an important micronutrient which may improve plant growth and development. Therefore, a research was undertaken to clarify the role of zinc on growth of soybean under salt stress. The experiment was conducted using six levels $(0,50,100,150,200$ and $250 \mathrm{mM})$ of $\mathrm{NaCl}$ and the plant was also treated with zinc under different salinity levels. This experiment was arranged in a completely randomized design with three replications. Maximum salt stress $(250 \mathrm{mM} \mathrm{NaCl})$ caused reduction in plant height by $64.35 \%, 58.82 \%, 56.90 \%$ and $57.37 \%$, leaf number by $72.68 \%, 65.31 \%, 57.57 \%$ and $53.41 \%$ and leaf area by $84.31 \%, 76.67 \%, 70.61 \%$, and $67.96 \%$ at $15,30,45$ and 60 days after treatment, respectively. Whereas, application of $\mathrm{Zn}$ to salt-stressed plants elevated plant height by $82.38 \%, 49.24 \%, 49.93 \%$, and $43.51 \%$, leaf number by $41.02 \%, 16.48 \%, 2.61 \%$, and $11.28 \%$ and leaf area by $41.85 \%, 40.09 \%, 18.47 \%$ and $17.67 \%$ at $15,30,45$ and 60 days after treatment, respectively. These results indicate that zinc plays an important role on growth of salt-stressed soybean. $\mathrm{Zn}$ application compensated the deleterious effects of $\mathrm{Na}^{+}$and $\mathrm{Cl}^{-}$ions and led to greater plant growth.
\end{abstract}

Keywords: Salinity, Growth, Yield, Soybean

\section{Introduction}

Salinity is one of the major environmental stresses hampering crop growth and development, consequently lowering global crop production. About 1125 million hectares of land worldwide are salt-affected, which represents $6 \%$ of world's total area including $20 \%$ of cultivated and $33 \%$ of the arable land $[1,2]$

The impact of salt stress is in the reduction of plant growth which is initially caused by osmotic stress and then followed by ion toxicity [3]. Furthermore, salt accumulation in leaves leading to salt toxicity in the plants. Moreover, In plant cells, the plethora of toxic ions causing damages in membrane systems and organelles, leading to reduced plant growth and abnormal development prior to plant death [4-6]. Salt stress causes changes in gene expression in the majority of plants, accelerating the synthesis of osmoprotectors and osmoregulators [7]. Salinity often leads to increased uptake of $\mathrm{Na}^{+}$or decreased uptake of $\mathrm{Ca}^{2+}$ and $\mathrm{K}^{+}$in leaves which causes nutritional imbalances [8]. Salt stress causing the death of leaves due to scarcity of nutrients, therefore reducing the total photosynthetic leaf area which reduces the supply of photosynthate in plants and ultimately it affects the yields [9].

Zinc is a crucial element for plant growth, as it is involved in various vital cellular functions such as protein, carbohydrate, and carbon metabolism, as well as IAA metabolism and cell division [10-13]. Zn supplementation could potentially assist to combat salt-induced harmful effects [14-17].

Soybean (Glycine max) belongs to fabaceae family native to East Asia, widely grown for its edible bean which has numerous uses. Dry soybean contain $36 \%$ protein, $19 \%$ oil, $35 \%$ carbohydrate (17\% of which dietary fiber), $5 \%$ minerals and several other components including vitamins [18]. According to FAO [19], globally the total annual production of soybean is 260.91 million tons from an area of 102.99 million hectares. Farmers in Bangladesh grow cereal crops on good soil for food security, but they cultivate non-cereal crops on marginal terrain, such as the southern coastal strip. In contrast, around $20 \%$ of land in southern coastal strip of 
Bangladesh is afflicted by varied degrees of salinity [20]. Soybean cultivation covers a total area of 41440 hectares, yielding 65883 tons of oil every year [19]. There is increasing evidence that salt stress has a major impact on growth and yield of soybean, making it as a salt sensitive crop. However, soybean production may not achieve its goal due to natural disasters, soil salinity and ambient air pollution in Bangladesh. As a result, the current study tried to explore the combined effects of $\mathrm{Zn}$ and salinity on different growth stage of soybean (cv. Shohag).

\section{Materials and Methods}

\subsection{Plant Materials}

Soybean (cv. Shohag) seeds were obtained from the Bangladesh Agricultural Research Institute (BARI) and used as plant materials.

\subsection{Treatments}

The experiment used a completely randomized design with three replications. Treatments were performed at six $\mathrm{NaCl}$ concentrations $(0,50,100,150,200$ and $250 \mathrm{mM})$ with and without zinc addition.

\subsection{Pot preparation and Management Practices}

Pot experiment were conducted in the experimental field of Jahangirnagar University's Botanical Garden in Savar, Dhaka. The soil sample was air-dried and pulverized. Before sowing $0.41 \mathrm{gm}$ TSP, $0.5 \mathrm{gm}$ MP was mixed into the soil per pot, and enough water was added to saturate the soil. Then zinc was combined thoroughly with soil at a rate of $10 \mathrm{mg}$ $\mathrm{kg}^{-1}$ as $\mathrm{ZnSO}_{4} .7 \mathrm{H}_{2} \mathrm{O} .18$ pots were filled with zinc treated soil. The pots were kept under natural sunshine till harvesting. The seeds were surface sterilized by soaking them for three minutes in $0.1 \%$ sodium hypochlorite and then washing them three times in distilled water. Seeds of uniform size were directly sown on $4^{\text {th }}$ February 2019 . Distilled water was applied in all pots up to the emergence of seedlings. After seedling establishment distilled water in control pots and $12.5 \mathrm{mM} \mathrm{NaCl}$ solution were applied in salt treatment. When the first leaf appeared, actual amount of $\mathrm{NaCl}$ solution were applied. The salt solution was used until it became mature. Regular watering and weeding were made to ensure equal environmental condition throughout the experimental period.

\subsection{Measurement of Growth}

Plant height, leaf length, leaf breadth, leaf number and leaf area of soybean cultivar were measured at 15, 30, 45 and 60 days after treatment (DAT).

\subsection{Statistical Analysis}

Statistical analysis of the collected data was performed using Analysis of Variance (ANOVA). All statistical analysis was performed with the SPSS statistical package (SPSS program 16.00). The data were presented as the means for each treatment. Means were compared using the LSD test at the $5 \%$ probability level.

\section{Results}

\subsection{Plant Height}

The data on plant height of soybean cultivar recorded at 15 , 30, 45 and 60 DAT are presented in the Table 1. Plant height significantly influenced by salinity levels. Compared with control, plant height of soybean treated with $200 \mathrm{mM} \mathrm{NaCl}$ decreased by $47.94 \%, 51.38 \%, 49.21 \%$, and $52.54 \%$ at 15,30 , 45 and 60 DAT, respectively. Compared to plants subjected to $200 \mathrm{mM} \mathrm{NaCl}, \mathrm{Zn}$ supplementation $(200 \mathrm{mM} \mathrm{NaCl}+\mathrm{Zn})$ enhanced plant height by $52.02 \%, 50.16 \%, 46.75 \%$ and $39.95 \%$ at 15, 30, 45 and 60 DAT, respectively. Compared with control, heights of plants treated with $250 \mathrm{mM} \mathrm{NaCl}$ decreased by $64.35 \%, 58.82 \%, 56.90 \%$ and $57.37 \%$ at $15,30,45$ and 60 DAT, respectively. $\mathrm{Zn}$ supplementation $(250 \mathrm{mM} \mathrm{NaCl}+\mathrm{Zn})$ increased plant height by $82.38 \%, 49.24 \%, 49.93 \%$, and $43.51 \%$ at $15,30,45$, and $60 \mathrm{DAT}$, respectively, as compared to plants exposed to $250 \mathrm{mM} \mathrm{NaCl}$.

Table 1. Effects of zinc on plant height $(\mathrm{cm})$ of soybean $\mathrm{cv}$. Shohag at different days after treatment under salinity.

\begin{tabular}{|c|c|c|c|c|}
\hline \multirow{2}{*}{ Treatments } & \multicolumn{4}{|c|}{ Days after treatment (DAT) } \\
\hline & 15 & 30 & 45 & 60 \\
\hline $0 \mathrm{mM} \mathrm{NaCl}$ & $68.83 \pm 2.36 \mathrm{a}$ & $82.00 \pm 2.64 \mathrm{a}$ & $91.80 \pm 2.45 \mathrm{a}$ & $109.07 \pm 5.95 \mathrm{a}$ \\
\hline $50 \mathrm{mM} \mathrm{NaCl}$ & $58.00 \pm 5.57 \mathrm{~b}(84.27)$ & $74.40 \pm 4.05$ a $(90.73)$ & $78.80 \pm 2.52 \mathrm{~b}(85.84)$ & $83.93 \pm 4.86$ b (76.95) \\
\hline $50 \mathrm{mM} \mathrm{NaCl}+\mathrm{Zn}$ & $65.67 \pm 4.21 \mathrm{ab}(95.41)$ & $76.37 \pm 5.51 \mathrm{~b}(93.13)$ & $82.17 \pm 8.27$ b $(89.51)$ & $99.17 \pm 5.53$ b (90.92) \\
\hline $100 \mathrm{mM} \mathrm{NaCl}$ & $45.47 \pm 3.50 \mathrm{c}(66.06)$ & $53.83 \pm 9.46 \mathrm{~b}(65.64)$ & $61.70 \pm 7.45 \mathrm{c}(67.21)$ & $68.76 \pm 7.86 \mathrm{c}(63.04)$ \\
\hline $100 \mathrm{mM} \mathrm{NaCl}+\mathrm{Zn}$ & $65.33 \pm 4.51 \mathrm{ab}(94.91)$ & $71.00 \pm 8.19$ b (86.59) & $78.20 \pm 6.72$ b (85.19) & $87.17 \pm 7.75$ bc (79.92) \\
\hline $150 \mathrm{mM} \mathrm{NaCl}$ & $38.67 \pm 2.08 \mathrm{~d}(56.18)$ & $47.67 \pm 4.5$ bc $(58.13)$ & $51.83 \pm 3.17 \mathrm{~d}(56.46)$ & $58.27 \pm 9.53 \mathrm{~cd}(53.42)$ \\
\hline $150 \mathrm{mM} \mathrm{NaCl}+\mathrm{Zn}$ & $58.27 \pm 11.12 \mathrm{abc}(84.66)$ & $63.10 \pm 9.85$ bc $(76.95)$ & $70.43 \pm 12.04 \mathrm{bc}(76.72)$ & $75.00 \pm 4.36 \mathrm{~cd}(68.76)$ \\
\hline $200 \mathrm{mM} \mathrm{NaCl}$ & $35.83 \pm 1.93 \mathrm{~d}(52.06)$ & $39.87 \pm 3.35 \mathrm{~cd}(48.62)$ & $46.63 \pm 2.03$ de $(50.79)$ & $51.77 \pm 1.37 \mathrm{de}(47.46)$ \\
\hline $200 \mathrm{mM} \mathrm{NaCl}+\mathrm{Zn}$ & $54.47 \pm 10.04$ bc $(79.65)$ & $59.87 \pm 9.27 \mathrm{bc}(73.01)$ & $68.43 \pm 4.40$ bc $(74.54)$ & $72.47 \pm 3.05 \mathrm{~d}(66.44)$ \\
\hline $250 \mathrm{mM} \mathrm{NaCl}$ & $24.40 \pm 4.41$ e $(35.45)$ & $33.77 \pm 4.13 \mathrm{~d}(41.18)$ & $39.57 \pm 4.50$ e $(43.10)$ & $46.50 \pm 4.27$ e $(42.63)$ \\
\hline $250 \mathrm{mM} \mathrm{NaCl}+\mathrm{Zn}$ & $44.50 \pm 8.32$ c $(64.65)$ & $50.40 \pm 9.18$ c $(61.46)$ & $59.33 \pm 8.33$ c $(64.63)$ & $66.73 \pm 6.60 \mathrm{~d}(61.18)$ \\
\hline
\end{tabular}

* Average value of 9 plants in each treatment.

* Means in a column followed by the same letter do not differ significantly at $5 \%$ level and \pm means standard deviation.

* Values within parenthesis indicate percentage relative to the control. 


\subsection{Leaf Number}

The data on leaf number of soybean cultivar recorded at $15,30,45$ and 60 DAT are presented in the Table 2. Salinity disturbed seriously the production of leaf, which was depicted in the stiff reduction in leaf number/plant with the increasing levels of salinity. Compared with control, leaf number of plants treated with $200 \mathrm{mM} \mathrm{NaCl}$ decreased by $72.68 \%, 57.14 \%, 48.11 \%$ and $44.81 \%$ at $15,30,45$ and 60 DAT, respectively. Compared to plants subjected to $200 \mathrm{mM}$
$\mathrm{NaCl}$, Zn supplementation $(200 \mathrm{mM} \mathrm{NaCl}+\mathrm{Zn})$ enhanced leaf number by $90 \%, 25.71 \%, 11.65 \%, 16.24 \%$ at $15,30,45$ and 60 DAT, respectively. Compared with control, leaf number of plants treated with $250 \mathrm{mM} \mathrm{NaCl}$ decreased by $72.68 \%, 65.31 \%, 57.57 \%$ and $53.41 \%$ at $15,30,45$ and 60 DAT, respectively. Zn supplementation $(250 \mathrm{mM} \mathrm{NaCl}+\mathrm{Zn})$ increased leaf number by $41.02 \%, 16.48 \%, 2.61 \%$, and $11.28 \%$ at $15,30,45$, and 60 DAT, respectively, as compared to plants exposed to $250 \mathrm{mM} \mathrm{NaCl}$.

Table 2. Effects of zinc on leaf number of soybean cv. Shohag at different days after treatment under salinity.

\begin{tabular}{|c|c|c|c|c|}
\hline \multirow{2}{*}{ Treatments } & \multicolumn{4}{|c|}{ Days after treatment (DAT) } \\
\hline & 15 & 30 & 45 & 60 \\
\hline $0 \mathrm{mM} \mathrm{NaCl}$ & $68.33 \pm 19.86 \mathrm{a}$ & $81.67 \pm 17.50 \mathrm{a}$ & $90.33 \pm 8.50 \mathrm{a}$ & $93.00 \pm 10.15 \mathrm{a}$ \\
\hline $50 \mathrm{mM} \mathrm{NaCl}$ & $59.33 \pm 9.87 \mathrm{ab}(86.83)$ & $71.67 \pm 10.24 \mathrm{ab}(87.75)$ & $79.17 \pm 2.25$ b $(87.64)$ & $83.60 \pm 5.71$ a $(89.89)$ \\
\hline $50 \mathrm{mM} \mathrm{NaCl}+\mathrm{Zn}$ & $67.67 \pm 2.04 \mathrm{ab}(99.03)$ & $78.33 \pm 3.57 \mathrm{ab}(95.91)$ & $84.00 \pm 3.00$ b (92.99) & $90.67 \pm 2.08 \mathrm{ab}(97.49)$ \\
\hline $100 \mathrm{mM} \mathrm{NaCl}$ & $52.00 \pm 17.98 \mathrm{ab}(76.10)$ & $66.33 \pm 10.65 \mathrm{abc}(81.22)$ & $62.00 \pm 7.00$ c $(68.64)$ & $68.30 \pm 8.61 \mathrm{~b}(73.44)$ \\
\hline $100 \mathrm{mM} \mathrm{NaCl}+\mathrm{Zn}$ & $58.33 \pm 1.53$ bc $(85.36)$ & $63.33 \pm 3.51$ bc $(77.54)$ & $68.67 \pm 4.04$ bc $(76.02)$ & $82.67 \pm 5.50$ bc $(88.89)$ \\
\hline $150 \mathrm{mM} \mathrm{NaCl}$ & $25.00 \pm 19.97 \mathrm{~b}(36.59)$ & $43.33 \pm 17.16 \mathrm{abc}(53.04)$ & $51.17 \pm 3.88 \mathrm{~d}(56.65)$ & $58.27 \pm 9.53$ bc $(62.66)$ \\
\hline $150 \mathrm{mM} \mathrm{NaCl}+\mathrm{Zn}$ & $47.67 \pm 9.29 \mathrm{~cd}(69.76)$ & $59.00 \pm 6.55 \mathrm{~cd}(72.24)$ & $62.67 \pm 5.68$ c $(69.38)$ & $68.67 \pm 5.09 \mathrm{~cd}(73.84)$ \\
\hline $200 \mathrm{mM} \mathrm{NaCl}$ & $20.00 \pm 24.25 \mathrm{~b}(29.27)$ & $35.00 \pm 27.79$ bc $(42.86)$ & $46.87 \pm 1.63 \mathrm{~d}$ e $(51.89)$ & $51.33 \pm 2.08 \mathrm{~cd}(55.19)$ \\
\hline $200 \mathrm{mM} \mathrm{NaCl}+\mathrm{Zn}$ & $38.00 \pm 9.53$ de $(55.61)$ & $44.00 \pm 8.54$ de $(53.88)$ & $52.33 \pm 9.01 \mathrm{~cd}(57.93)$ & $59.67 \pm 7.23 \mathrm{de}(64.16)$ \\
\hline $250 \mathrm{mM} \mathrm{NaCl}$ & $18.67 \pm 9.07 \mathrm{~b}(27.32)$ & $28.33 \pm 13.05$ c (34.69) & $38.33 \pm 3.05$ e $(42.43)$ & $43.43 \pm 3.21 \mathrm{~d}(46.59)$ \\
\hline $250 \mathrm{mM} \mathrm{NaCl}+\mathrm{Zn}$ & $26.33 \pm 6.66$ e $(38.53)$ & $33.00 \pm 7.55$ e $(40.41)$ & $39.33 \pm 3.52 \mathrm{~d}(43.54)$ & $48.33 \pm 7.02$ e $(51.97)$ \\
\hline
\end{tabular}

* Average value of 9 plants in each treatment.

* Means in a column followed by the same letter do not differ significantly at $5 \%$ level and \pm means standard deviation.

* Values within parenthesis indicate percentage relative to the control.

\subsection{Leaf Length}

The data on leaf length of soybean cultivar recorded at 15 , 30,45 and 60 DAT are presented in the Table 3. Compared with control, leaf length of plants treated with $200 \mathrm{mM} \mathrm{NaCl}$ decreased by $49.91 \%, 45.89 \%, 41.47 \%$ and $39.45 \%$ at 15,30 , 45 and 60 DAT, respectively. Compared to plants subjected to $200 \mathrm{mM} \mathrm{NaCl}, \mathrm{Zn}$ application $(200 \mathrm{mM} \mathrm{NaCl}+\mathrm{Zn})$ enhanced leaf length by $24.33 \%, 6.07 \%, 2.67 \%$ and $4.5 \%$ at $15,30,45$ and 60 DAT, respectively. Compared with control, leaf length of plants treated with $250 \mathrm{mM} \mathrm{NaCl}$ decreased by $60.77 \%, 46.06 \%, 42.72 \%$, and $40.37 \%$ at $15,30,45$ and 60 DAT, respectively. Compared to plants subjected to $250 \mathrm{mM}$ $\mathrm{NaCl}, \mathrm{Zn}$ application $(250 \mathrm{mM} \mathrm{NaCl}+\mathrm{Zn})$ enhanced leaf length by $5.34 \%, 6.7 \%, 1.4 \%$ and $2.8 \%$ at $15,30,45$ and 60 DAT, respectively.

Table 3. Effects of zinc on leaf length $(\mathrm{cm})$ of soybean $\mathrm{cv}$ Shohag at different days after treatment under salinity.

\begin{tabular}{|c|c|c|c|c|}
\hline \multirow{2}{*}{ Treatments } & \multicolumn{4}{|c|}{ Days after treatment (DAT) } \\
\hline & 15 & 30 & 45 & 60 \\
\hline $0 \mathrm{mM} \mathrm{NaCl}$ & $10.50 \pm 2.65 \mathrm{a}$ & $12.16 \pm 1.49 \mathrm{a}$ & $12.78 \pm 1.06 \mathrm{a}$ & $13.08 \pm 1.29 \mathrm{a}$ \\
\hline $50 \mathrm{mM} \mathrm{NaCl}$ & $8.74 \pm 3.09 \mathrm{a}(83.24)$ & $11.10 \pm 2.35 \mathrm{ab}(91.28)$ & $11.72 \pm 1.81 \mathrm{ab}(91.70)$ & $12.00 \pm 1.74 \mathrm{ab}(91.74)$ \\
\hline $50 \mathrm{mM} \mathrm{NaCl}+\mathrm{Zn}$ & $10.02 \pm 2.39 \mathrm{~b}(95.43)$ & $10.52 \pm 2.28 \mathrm{~b}(86.51)$ & $12.30 \pm 0.82 \mathrm{~b}(96.24)$ & $12.44 \pm 0.53$ a $(95.11)$ \\
\hline $100 \mathrm{mM} \mathrm{NaCl}$ & $5.04 \pm 0.55 \mathrm{~b}(48.00)$ & $7.24 \pm 1.25 \mathrm{~cd}(59.54)$ & $8.28 \pm 1.42$ c $(64.79)$ & $8.72 \pm 1.50 \mathrm{~cd}(66.67)$ \\
\hline $100 \mathrm{mM} \mathrm{NaCl}+\mathrm{Zn}$ & $7.78 \pm 1.55$ c (74.09) & $8.36 \pm 1.53$ c $(68.75)$ & $9.14 \pm 1.07$ c (71.52) & $9.76 \pm 0.78 \mathrm{~b}(74.62)$ \\
\hline $150 \mathrm{mM} \mathrm{NaCl}$ & $6.20 \pm 1.48 \mathrm{~b}(57.33)$ & $9.56 \pm 1.12$ bc $(78.62)$ & $10.50 \pm 1.54 \mathrm{~b}(82.16)$ & $10.68 \pm 1.69$ bc $(81.65)$ \\
\hline $200 \mathrm{mM} \mathrm{NaCl}$ & $5.26 \pm 1.29 \mathrm{~b}(50.09)$ & $6.58 \pm 1.90 \mathrm{~d}(54.11)$ & $7.48 \pm 1.73$ c $(58.53)$ & $7.92 \pm 1.84 \mathrm{~d}(60.55)$ \\
\hline $200 \mathrm{mM} \mathrm{NaCl}+\mathrm{Zn}$ & $6.54 \pm 1.32$ c (62.29) & $6.98 \pm 1.35 \mathrm{~cd}(57.40)$ & $7.68 \pm 0.64 \mathrm{~d}(60.09)$ & $8.28 \pm 1.36 \mathrm{c}(63.30)$ \\
\hline $250 \mathrm{mM} \mathrm{NaCl}$ & $4.12 \pm 1.09 \mathrm{~b}(39.23)$ & $6.56 \pm 2.30 \mathrm{~d}(53.94)$ & $7.32 \pm 1.99$ c $(57.28)$ & $7.80 \pm 2.01 \mathrm{~d}(59.63)$ \\
\hline $250 \mathrm{mM} \mathrm{NaCl}+\mathrm{Zn}$ & $4.34 \pm 1.02 \mathrm{~d}(41.33)$ & $7.00 \pm 1.03 \mathrm{~d}(57.54)$ & $7.42 \pm 0.51 \mathrm{~d}(58.06)$ & $8.02 \pm 0.73 \mathrm{c}(61.31)$ \\
\hline
\end{tabular}

* Average value of 9 plants in each treatment.

* Means in a column followed by the same letter do not differ significantly at 5\% level and \pm means standard deviation.

* Values within parenthesis indicate percentage relative to the control.

\subsection{Leaf Breadth}

The data on leaf breadth of soybean cultivar recorded at $15,30,45$ and 60 DAT are presented in the Table 4. Compared with control, leaf breadth of plants treated with
$200 \mathrm{mM} \mathrm{NaCl}$ decreased by $44.23 \%, 41.78 \%, 40.64 \%$ and $36.83 \%$ at $15,30,45$ and $60 \mathrm{DAT}$, respectively. Compared to plants subjected to $200 \mathrm{mM} \mathrm{NaCl}, \mathrm{Zn}$ application $(200 \mathrm{mM}$ $\mathrm{NaCl}+\mathrm{Zn}$ ) enhanced leaf breadth to $12.76 \%, 7.06 \%, 13.01 \%$ and $27.57 \%$. Compared with control, leaf breadth of plants 
treated with $250 \mathrm{mM} \mathrm{NaCl}$ decreased by $60.69 \%, 56.93 \%$, $48.98 \%$, and $46.14 \%$ at $15,30,45$ and 60 DAT, respectively. Compared to plants subjected to $250 \mathrm{mM} \mathrm{NaCl}, \mathrm{Zn}$ application $(250 \mathrm{mM} \mathrm{NaCl}+\mathrm{Zn})$ enhanced leaf breadth to $40.63 \%, 30.15 \%, 16.73 \%$ and $38.60 \%$ at $15,30,45$ and 60 DAT, respectively.

Table 4. Effects of zinc on leaf breadth (cm) of soybean cv. Shohag at different days after treatment under salinity.

\begin{tabular}{|c|c|c|c|c|}
\hline \multirow{2}{*}{ Treatments } & \multicolumn{4}{|c|}{ Days after treatment (DAT) } \\
\hline & 15 & 30 & 45 & 60 \\
\hline $0 \mathrm{mM} \mathrm{NaCl}$ & $8.14 \pm 1.09 \mathrm{a}$ & $9.24 \pm 1.22 \mathrm{a}$ & $9.84 \pm 0.92 \mathrm{a}$ & $10.10 \pm 0.93 \mathrm{a}$ \\
\hline $50 \mathrm{mM} \mathrm{NaCl}$ & $7.30 \pm 0.84 \mathrm{a}(89.68)$ & $7.94 \pm 0.80 \mathrm{ab}(85.93)$ & $8.40 \pm 0.92 \mathrm{~b}(85.37)$ & $8.98 \pm 0.98 \mathrm{ab}(88.91)$ \\
\hline $50 \mathrm{mM} \mathrm{NaCl}+\mathrm{Zn}$ & $6.98 \pm 0.89 \mathrm{ab}(85.75)$ & $7.86 \pm 0.92 \mathrm{ab}(85.06)$ & $8.26 \pm 0.87 \mathrm{ab}(83.94)$ & $8.86 \pm 0.99 \mathrm{ab}(87.72)$ \\
\hline $100 \mathrm{mM} \mathrm{NaCl}$ & $5.52 \pm 1.62 \mathrm{~b}(67.81)$ & $6.52 \pm 1.68 \mathrm{bc}(70.56)$ & $7.24 \pm 1.75 \mathrm{~b}(73.58)$ & $7.7 \pm 1.74 \mathrm{ab}(76.24)$ \\
\hline $100 \mathrm{mM} \mathrm{NaCl}+\mathrm{Zn}$ & $6.30 \pm 1.67 \mathrm{abc}(77.39)$ & $7.28 \pm 1.61 \mathrm{ab}(78.79)$ & $7.66 \pm 1.81 \mathrm{abc}(77.85)$ & $6.98 \pm 0.91 \mathrm{ab}(69.11)$ \\
\hline $150 \mathrm{mM} \mathrm{NaCl}$ & $4.26 \pm 0.85$ bc $(52.33)$ & $5.08 \pm 0.79 \mathrm{~cd}(54.98)$ & $5.8 \pm 0.94 \mathrm{~cd}(58.94)$ & $6.44 \pm 0.99$ bc $(63.76)$ \\
\hline $200 \mathrm{mM} \mathrm{NaCl}$ & $4.54 \pm 1.36 \mathrm{bc}(55.77)$ & $5.38 \pm 1.31 \mathrm{~cd}(58.22)$ & $5.84 \pm 1.15 \mathrm{~cd}(59.36)$ & $6.38 \pm 1.20 \mathrm{bc}(63.17)$ \\
\hline $200 \mathrm{mM} \mathrm{NaCl}+\mathrm{Zn}$ & $5.12 \pm 1.60 \mathrm{bc}(62.89)$ & $5.76 \pm 1.37 \mathrm{~cd}(62.33)$ & $6.60 \pm 1.11 \mathrm{bc}(67.07)$ & $8.14 \pm 1.74$ bc $(80.59)$ \\
\hline $250 \mathrm{mM} \mathrm{NaCl}$ & $3.20 \pm 0.84$ c $(39.31)$ & $3.98 \pm 0.62 \mathrm{~d}(43.07)$ & $5.02 \pm 0.55 \mathrm{~d}(51.02)$ & $5.44 \pm 0.48 \mathrm{c}(53.86)$ \\
\hline $250 \mathrm{mM} \mathrm{NaCl}+\mathrm{Zn}$ & $4.50 \pm 1.31 \mathrm{c}(55.28)$ & $5.18 \pm 1.27 \mathrm{~d}(56.06)$ & $5.86 \pm 1.14$ c $(59.55)$ & $7.54 \pm 1.54$ c (74.65) \\
\hline
\end{tabular}

* Average value of 9 plants in each treatment.

* Means in a column followed by the same letter do not differ significantly at $5 \%$ level and \pm means standard deviation.

* Values within parenthesis indicate percentage relative to the control.

\subsection{Leaf Area}

The data on leaf area of soybean cultivar recorded at 15 , 30, 45 and 60 DAT are presented in the Table 5. Compared with control leaf area of plant treated with $200 \mathrm{mM} \mathrm{NaCl}$ decreased by $72.62 \%, 68.38 \%, 65.52 \%$ and $61.94 \%$ at 15,30 , 45 and 60 DAT, respectively. Compared to plants subjected to $200 \mathrm{mM} \mathrm{NaCl}, \mathrm{Zn}$ application $(200 \mathrm{mM} \mathrm{NaCl}+\mathrm{Zn})$ enhanced leaf area by $43.81 \%, 14.22 \%, 17.32 \%$ and $15.05 \%$ at 15, 30, 45 and 60 DAT, respectively. Compared with control, leaf area of plant treated with $250 \mathrm{mM} \mathrm{NaCl}$ decreased by $84.31 \%, 76.67 \%, 70.61 \%$, and $67.96 \%$ at 15 , 30, 45 and 60 DAT, respectively. Compared to plants subjected to $250 \mathrm{mM} \mathrm{NaCl}, \mathrm{Zn}$ application $(250 \mathrm{mM} \mathrm{NaCl}+$ $\mathrm{Zn})$ enhanced leaf area by $41.85 \%, 40.09 \%, 18.47 \%$ and $17.67 \%$ at $15,30,45$ and 60 DAT, respectively.

Table 5. Effects of zinc on leaf area ( $\mathrm{cm}^{2} /$ plant) of soybean $\mathrm{cv}$. Shohag at different days after treatment under salinity.

\begin{tabular}{|c|c|c|c|c|}
\hline \multirow{2}{*}{ Treatments } & \multicolumn{4}{|c|}{ Days after treatment (DAT) } \\
\hline & 15 & 30 & 45 & 60 \\
\hline $0 \mathrm{mM} \mathrm{NaCl}$ & $85.29 \pm 23.57 \mathrm{a}$ & $111.85 \pm 16.39 \mathrm{a}$ & $125.07 \pm 6.07 \mathrm{a}$ & $131.41 \pm 9.95 \mathrm{a}$ \\
\hline $50 \mathrm{mM} \mathrm{NaCl}$ & $65.00 \pm 26.11 \mathrm{~b}(76.21)$ & $89.58 \pm 25.23 \mathrm{~b}(80.08)$ & $98.16 \pm 17.26 \mathrm{~b}(78.48)$ & $108.99 \pm 14.68 \mathrm{~b}(82.93)$ \\
\hline $50 \mathrm{mM} \mathrm{NaCl}+\mathrm{Zn}$ & $69.56 \pm 17.18 \mathrm{~b}(81.56)$ & $82.61 \pm 20.81 \mathrm{~b}(73.86)$ & $101.79 \pm 14.71$ a $(81.39)$ & $110.02 \pm 10.93 \mathrm{~b}(83.73)$ \\
\hline $100 \mathrm{mM} \mathrm{NaCl}$ & $27.24 \pm 5.84$ c (31.94) & $47.87 \pm 17.72$ c (42.79) & $60.29 \pm 20.31 \mathrm{c}(48.20)$ & $67.92 \pm 23.64$ c (51.69) \\
\hline $100 \mathrm{mM} \mathrm{NaCl}+\mathrm{Zn}$ & $46.03 \pm 16.47 \mathrm{c}(53.97)$ & $58.61 \pm 16.23$ c $(52.40)$ & $70.53 \pm 19.69 \mathrm{~b}(56.39)$ & $79.78 \pm 19.29$ c $(60.71)$ \\
\hline $150 \mathrm{mM} \mathrm{NaCl}$ & $26.36 \pm 7.59$ c $(30.91)$ & $48.49 \pm 9.40 \mathrm{c}(43.35)$ & $60.60 \pm 12.09$ c $(48.45)$ & $68.18 \pm 12.27$ c (51.89) \\
\hline $200 \mathrm{mM} \mathrm{NaCl}$ & $23.35 \pm 7.85 \mathrm{c}(27.38)$ & $35.37 \pm 14.18$ c (31.62) & $43.12 \pm 11.31 \mathrm{~cd}(34.48)$ & $50.01 \pm 13.72 \mathrm{~cd}(38.06)$ \\
\hline $200 \mathrm{mM} \mathrm{NaCl}+\mathrm{Zn}$ & $33.58 \pm 13.39 \mathrm{~cd}(39.37)$ & $40.40 \pm 13.38 \mathrm{~cd}(35.47)$ & $50.59 \pm 8.92 \mathrm{bc}(40.44)$ & $57.54 \pm 9.75 \mathrm{~cd}(43.78)$ \\
\hline $250 \mathrm{mM} \mathrm{NaCl}$ & $13.38 \pm 5.54 \mathrm{c}(15.69)$ & $25.09 \pm 9.86 \mathrm{c}(23.33)$ & $36.77 \pm 10.84$ d (29.39) & $42.10 \pm 9.39 \mathrm{~d}(32.04)$ \\
\hline $250 \mathrm{mM} \mathrm{NaCl}+\mathrm{Zn}$ & $18.98 \pm 4.71 \mathrm{~d}(22.25)$ & $35.15 \pm 5.55 \mathrm{~d}(31.42)$ & $43.56 \pm 9.62 \mathrm{c}(34.82)$ & $49.54 \pm 12.91 \mathrm{~d}(37.69)$ \\
\hline
\end{tabular}

* Average value of 9 plants in each treatment.

* Means in a column followed by the same letter do not differ significantly at $5 \%$ level and \pm means standard deviation.

* Values within parenthesis indicate percentage relative to the control.

\section{Discussion}

It was observed that the height of soybean plants decreased as the salinity level increased. Plant height reductions due to salinity has been reported in rice, [21], soybean [20], lemon balm [22, 23]. Mazher et al. [24] stated that the detrimental effect of salt on photosynthesis, changes in enzyme activity and a decrease in carbohydrate and growth hormone levels could all contribute to the salt-induced reduction in plant height. Results showed that zinc application improved shoot and root length under all salinity treatments. Similar results have been reported by Ahmad et al. [16] and Weisany et al. 25]. Zinc enhances plant growth by stimulating cell division and proliferation by increasing natural auxin synthesis [26]. Moreover, proper concentration of zinc plays a critical role in membrane permeability, phospholipid accumulation and reactive oxygen species (ROS) detoxification under salinity [17, 27].

With increasing salinity, the production of leaf numbers was negatively impacted. Since the leaf is the primary photosynthetic organ, the leaf number is critical for plant development. Similar results of reduction in leaf number under saline conditions have been reported in rice [21], in purslane [28] and barley [29]. Under salt stress, the formation of leaf primordial is inhibited, which may be the cause of low leaf number [30]. Additionally, 
the accumulation of sodium chloride in the cell walls and cytoplasm of older leaves may be causing the decline in leaf numbers. In contrast, zinc application increased leaf number in all salinity treatments. Similar result has also been found by Sarhan et al. [31]. Jiang et al. [32] demonstrated that Zn could aid nutrient translocations from old to new cells.

In this study, the leaf length and leaf breadth were adversely affected by salinity. The reduction in leaf length and leaf breadth were quite incremental at all salinity levels. The results are in confirmation with the findings of Ashrafuzzaman et al. [33]. However, when zinc was applied, leaf length and leaf breadth increased under salinity stress.

It is obvious that production of photosynthetic area is disturbed by abiotic stress [34]. As a result, the overall growth and development of a plant is severely disrupted. The decrease in green leaf area could be attributed to increased leaf senescence as well as smaller leaves formed under saline conditions. Several authors have been reported that leaf area per plant decreased markedly by salinity in rice $[35,36]$ in wheat $[37,38]$, in maize [33], in bean [39], black gram and mung bean [40]. Whereas, zinc application enhanced leaf area under all salinity treatments. Many scientists stated that applying $\mathrm{Zn}$ to crop plants in a saline environment improved leaf area [31, 41, 42]. It has been concluded that $\mathrm{Zn}$ nutrition may reduce negative salinity effects by promoting plant $\mathrm{Zn} / \mathrm{K}$ intake while restricting plant $\mathrm{Na}$ storage, resulting in increased leaf cell membrane stability, chlorophyll synthesis, and leaf water retention [43, 44].

\section{Conclusions}

This study concluded that salt stress negatively affects plant growth in terms of plant height, leaf number, leaf length, leaf breadth and leaf area. It can also be concluded that zinc and salinity interaction provides comparatively greater plant growth in soybean plants than salt stress alone. Overall, the findings suggest that zinc supplementation may reduce the harmful consequences of $\mathrm{NaCl}$ stress. Therefore, future experiments will be conducted to determine the mechanisms underlying the enhanced safety of soybean against the harmful effects of salt due to zinc application.

\section{Acknowledgements}

This study was supported by a grant from University Grants Commission, Bangladesh.

\section{References}

[1] M. S. Hossain, Present scenario of global salt affected soils, its management and importance of salinity research, Int. Res. J. Biol. Sci. 1 (2019) 1-3.

[2] N. Akhtar, F. Hossain, A. Karim, Influence of calcium on water relation of two cultivars of wheat under salt stress, Int. J. Environ. 2 (2013) 1-8. https://doi.org/10.3126/ije.v2i1.9202.

[3] B. Gupta, B. Huang, Mechanism of salinity tolerance in plants: physiological, biochemical, and molecular characterization, Int. J. Genomics. (2014). https://doi.org/10.1155/2014/701596.
[4] R. Davenport, R. A. James, A. Zakrisson-Plogander, M. Tester, R. Munns, Control of sodium transport in durum wheat, Plant Physiol. $137 \quad$ (2005) 807-818. https://doi.org/10.1104/pp.104.057307.

[5] J. M. Quintero, J. María Fournier, M. Benlloch, $\mathrm{Na}^{+}$ accumulation in shoot is related to water transport in $\mathrm{K}^{+}$. starved sunflower plants but not in plants with a normal $\mathrm{K}^{+}$ status, J. Plant Physiol. 164 (2007) 60-67. https://doi.org/10.1016/j.jplph.2005.10.010.

[6] K. Siringam, N. Juntawong, S. Cha-Um, C. Kirdmanee, Salt stress induced ion accumulation, ion homeostasis, membrane injury and sugar contents in salt-sensitive rice (Oryza sativa L. spp. indica) roots under isoosmotic conditions, African J. Biotechnol. 10 (2011) 1340-1346.

[7] J. Teixeira, S. Pereira, High salinity and drought act on an organ-dependent manner on potato glutamine synthetase expression and accumulation, Environ. Exp. Bot. 60 (2007) 121-126. https://doi.org/10.1016/j.envexpbot.2006.09.003.

[8] J. P. S. Neel, G. A. Alloush, D. P. Belesky, W. M. Clapham, Influence of rhizosphere ionic strength on mineral composition, dry matter yield and nutritive value of forage chicory, J. Agron. Crop Sci. 188 (2002) 398-407. https://doi.org/10.1046/j.1439-037X.2002.00593.x.

[9] R. Munns, Comparative physiology of salt and water stress,

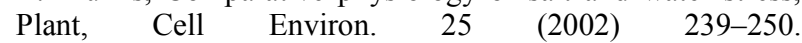
https://doi.org/10.1046/j.0016-8025.2001.00808.x.

[10] T. Tsonev, F. J. C. Lidon, Zinc in plants - An overview, Emirates J. Food Agric. 24 (2012) 322-333.

[11] M. H. Martin, H. Marschner, The mineral nutrition of higher plants., 2nd ed., Academic Press, London, 1988. https://doi.org/10.2307/2260650.

[12] J. Osredkar, N. Sustar, Copper and zinc, biological role and significance of copper/zinc imbalance, J. Clin. Toxicol. s3 (2011) 3. https://doi.org/10.4172/2161-0495.s3-001.

[13] S. Singh, P. Parihar, R. Singh, V. P. Singh, S. M. Prasad, Heavy metal tolerance in plants: role of transcriptomics, proteomics, metabolomics, and ionomics, Front. Plant Sci. 6 (2016) 1143. https://doi.org/10.3389/fpls.2015.01143.

[14] A. H. Saeidnejad, Alleviative effects of zinc on physiological properties and antioxidants activity of maize plants under salinity stress, Int. J. Agric. Crop Sci. 5 (2013) 529-537.

[15] W. Weisany, Y. Sohrabi, G. Heidari, A. Siosemardeh, H. Badakhshan, Effects of zinc application on growth, absorption and distribution of mineral nutrients under salinity stress in soybean (Glycine max L.), J. Plant Nutr. 37 (2014) 2255-2269. https://doi.org/10.1080/01904167.2014.920386.

[16] P. Ahmad, M. A. Ahanger, M. N. Alyemeni, L. Wijaya, D. Egamberdieva, R. Bhardwaj, M. Ashraf, Zinc application mitigates the adverse effects of $\mathrm{NaCl}$ stress on mustard [Brassica juncea (L.) czern \& coss] through modulating compatible organic solutes, antioxidant enzymes, and flavonoid content, J. Plant Interact. 12 (2017) 429-437. https://doi.org/10.1080/17429145.2017.1385867.

[17] S. Afrin, N. Akhtar, T. Khanam, F. Hossain, Alleviative effects of zinc on biomass yield and antioxidative enzymes activity in leaves of soybean (Glycine max L.) under salt stress, Am. J. Agric. For. 9 (2021) 147-155. https://doi.org/10.11648/j.ajaf.20210903.18. 
[18] K. Liu, chemistry and nutritional value of soybean components, in: Soybeans, Springer US, 1997: pp. 25-113. https://doi.org/10.1007/978-1-4615-1763-4 2.

[19] FAO, The multiple dimensions of food security, 2013.

[20] U. S. Hashi, A. Karim, H. M. Saikat, R. Islam, M. A. Islam, Effect of salinity and potassium levels on different morphophysiological characters of two soybean (Glycine max L.) genotypes, Rice Res. 3 (2015) 143.

[21] T. Khanam, N. Akhtar, M. Halim, F. Hossain, Effect of irrigation salinity on the growth and yield of two aus rice cultivars of Bangladesh, Jahangirnagar Univ. J. Biol. Sci. 7 (2018) 1-12. https://doi.org/10.3329/jujbs.v7i2.40742.

[22] A. Ozturk, A. Unlukara, A. Ipek, B. Gurbuz, Effects of salt stress and water deficit on plant growth and essential oil content of lemon balm (Melissa officinalis L.), Pakistan J. Bot. 36 (2004) 787-792.

[23] A. O. Sari, A. Ceylan, Yield characteristics and essential oil composition of lemon balm (Melissa officinalis L.) grown in the Aegean region of Turkey, Turkish J. Agric. For. 26 (2002) 217-224. https://doi.org/10.3906/tar-0110-6.

[24] A. M. A. Mazher, E. M. F. El-Quesni, M. M. Farahat, Responses of ornamental and woody trees to salinity, World J. Agric. Sci. 3 (2007) 386-395.

[25] W. Weisany, Y. Sohrabi, G. Heidari, A. Siosemardeh, K. Ghassemi-Golezani, Changes in antioxidant enzymes activity and plant performance by salinity stress and zinc application in soybean (Glycine max L.), Plant Omics. 5 (2012) 60-67.

[26] E. A. Ali, A. M. Mahmoud, Effect of foliar spray by different salicylic acid and zinc concentrations on seed yield and yield components of mungbean in sandy soil, Asian J. Crop Sci. 5 (2013) 33-40. https://doi.org/10.3923/ajcs.2013.33.40.

[27] H. Inada, T. Kondo, N. Akhtar, D. Hoshino, M. Yamaguchi, T. Izuta, Relationship between cultivar difference in the sensitivity of net photosynthesis to ozone and reactive oxygen species scavenging system in Japanese winter wheat (Triticum aestivum), Physiol. Plant. 146 (2012) 217-227.

[28] M. A. Alam, A. S. Juraimi, M. Y. Rafii, A. A. Hamid, F. Aslani, M. A. Hakim, Salinity-induced changes in the morphology and major mineral nutrient composition of purslane (Portulaca oleracea L.) accessions, Biol. Res. 49 (2016) 24. https://doi.org/10.1186/s40659-016-0084-5.

[29] E. R. R. Iyengar, J. S. Patolia, T. Kurian, Varietal differences in barley to salinity, Zeitschrift Für Pflanzenphysiologie. 84 (1977) 355-361. https://doi.org/10.1016/s0044-328x(77)80149-9.

[30] A. N. M. Alamgir, M. Yousuf Ali, Effects of $\mathrm{NaCl}$ salinity on leaf characters and physiological growth attributes of different genotypes of rice (Oryza sativa L.), Bangladesh J. Bot. 35 (2006) 99-107.

[31] A. Sarhan, A. Abd El-Dayem, A. Soliman, S. Sherbeeni, Effect of irrigation water salinity and zinc fertilization on growth of Swietenia macrophylla, J. Plant Prod. 9 (2018) 631635. https://doi.org/10.21608/jpp.2018.36371.
[32] W. Jiang, X. H. Sun, H. L. Xu, N. Mantri, H. F. Lu, Optimal concentration of zinc sulfate in foliar spray to alleviate salinity stress in Glycine soja, J. Agric. Sci. Technol. 16 (2014) 445-460.

[33] M. Ashrafuzzaman, M. A. Halim khan, S. M. Shahidullah, Response of vegetative growth of maize (Zea mays) to a range of salinity, J. Biol. Sci. 3 (2003) 253-258. https://doi.org/10.3923/jbs.2003.253.258.

[34] N. Akhtar, M. Yamaguchi, H. Inada, D. Hoshino, T. Kondo, M. Fukami, R. Funada, T. Izuta, Effects of ozone on growth, yield and leaf gas exchange rates of four Bangladeshi cultivars of rice (Oryza sativa L.), Environ. Pollut. 158 (2010b) 2970 2976. https://doi.org/10.1016/j.envpol.2010.05.026.

[35] F. Gholizadeh, S. Navabpour, Effect of salinity on morphological and physiological characteristics in correlation to selection of salt tolerance in rice (Oryza sativa L.), Int. J. $\begin{array}{lllll}\text { Agric. } & \text { Res. } & 6 & \text { (2011) }\end{array}$ https://doi.org/10.3923/ijar.2011.780.788.

[36] S. D. Wankhade, M. J. Cornejo, I. Mateu-Andrés, A. Sanz, Morpho-physiological variations in response to $\mathrm{NaCl}$ stress during vegetative and reproductive development of rice, Acta Physiol. Plant. 35 (2013) 323-333. https://doi.org/10.1007/s11738-012-1075-y.

[37] H. Saneoka, K. Shiota, H. Kurban, M. I. Chaudhary, G. S. Premachandra, K. Fujita, Effect of salinity on growth and solute accumulation in two wheat lines differing in salt tolerance, Soil Sci. Plant Nutr. 45 (1999) 873-880. https://doi.org/10.1080/00380768.1999.10414336.

[38] N. Akhtar, M. Yamaguchi, H. Inada, D. Hoshino, T. Kondo, T. Izuta, Effects of ozone on growth, yield and leaf gas exchange rates of two Bangladeshi cultivars of wheat (Triticum aestivum L.), Environ. Pollut. 158 (2010a) 1763-1767. https://doi.org/10.1016/j.envpol.2009.11.011.

[39] A. M. S. A. Qados, Effect of salt stress on plant growth and metabolism of bean plant Vicia faba (L.), J. Saudi Soc. Agric. Sci. $10 \quad$ (2011) 7-15. https://doi.org/10.1016/j.jssas.2010.06.002.

[40] P. K. Raptan, A. Hamid, Q. A. Khaliq, A. R. M. Solaiman, J. U. Ahmed, M. A. Karim, Salinity tolerance of blackgram and mungbean: I. Dry matter accumulation in different plant parts, Korean J. Crop Sci. 46 (2001) 380-386.

[41] A. Tantawy, Effect of some mineral and organic compounds on salinity tolerance in tomato, (2007).

[42] K. Parvin, M. Hasanuzzaman, M. Fujita, Supplemental zinc mitigates salt-induced damages in tomato (Lycopersicon esculentum L.), Int. J. Bus. Soc. Sci. Res. 5 (2016) 91-97.

[43] A. Tufail, H. Li, A. Naeem, T. X. Li, Leaf cell membrane stability-based mechanisms of zinc nutrition in mitigating salinity stress in rice, Plant Biol. 20 (2018) 338-345. https://doi.org/10.1111/plb.12665.

[44] M. Yamaguchi, D. Hoshino, H. Inada, N. Akhtar, C. Sumioka, K. Takeda, T. Izuta, Evaluation of the effects of ozone on yield of Japanese rice (Oryza sativa L.) based on stomatal ozone uptake, Environ. Pollut. 184 (2014) 472-480. https://doi.org/10.1016/j.envpol.2013.09.024. 